\title{
Practical synthesis of aryl-2-methyl-3-butyn-2-ols from aryl bromides via conventional and decarboxylative copper-free Sonogashira coupling reactions
}

\author{
Andrea Caporale $^{* 1}$, Stefano Tartaggia ${ }^{1}$, Andrea Castellin ${ }^{2}$
}

and Ottorino De Lucchi ${ }^{1}$

\section{Full Research Paper}

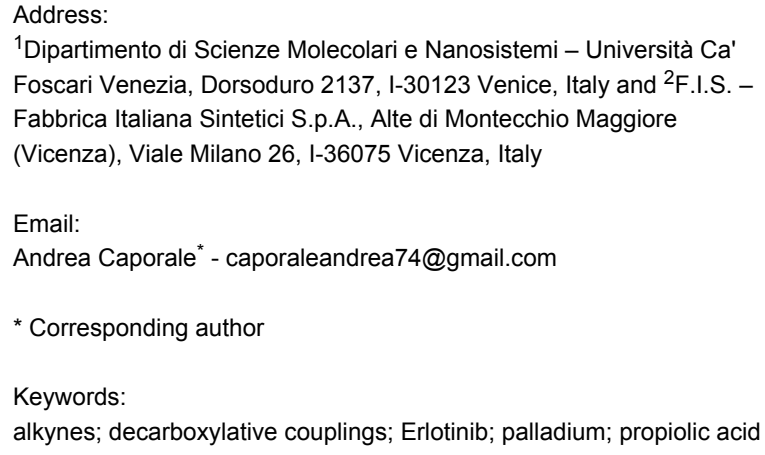

1'Dipartimento di Scienze Molecolari e Nanosistemi - Università Ca' Foscari Venezia, Dorsoduro 2137, I-30123 Venice, Italy and ${ }^{2}$ F.I.S. Fabbrica Italiana Sintetici S.p.A., Alte di Montecchio Maggiore (Vicenza), Viale Milano 26, I-36075 Vicenza, Italy

Email:

Andrea Caporale* - caporaleandrea74@gmail.com

* Corresponding author

Keywords:

alkynes; decarboxylative couplings; Erlotinib; palladium; propiolic acid

Beilstein J. Org. Chem. 2014, 10, 384-393.

doi:10.3762/bjoc. 10.36

Received: 18 November 2013

Accepted: 10 January 2014

Published: 12 February 2014

Associate Editor: K. Itami

(c) 2014 Caporale et al; licensee Beilstein-Institut.

License and terms: see end of document.

\begin{abstract}
Two efficient protocols for the palladium-catalyzed synthesis of aryl-2-methyl-3-butyn-2-ols from aryl bromides in the absence of copper were developed. A simple catalytic system consisting of $\mathrm{Pd}(\mathrm{OAc})_{2}$ and $\mathrm{P}(p \text {-tol })_{3}$ using $\mathrm{DBU}$ as the base and THF as the solvent was found to be highly effective for the coupling reaction of 2-methyl-3-butyn-2-ol (4) with a wide range of aryl bromides in good to excellent yields. Analogously, the synthesis of aryl-2-methyl-3-butyn-2-ols was performed also through the decarboxylative coupling reaction of 4-hydroxy-4-methyl-2-pentynoic acid with aryl bromides, using a catalyst containing $\mathrm{Pd}(\mathrm{OAc})_{2}$ in combination with SPhos or XPhos in the presence of tetra- $n$-butylammonium fluoride (TBAF) as the base and THF as the solvent. Therefore, new efficient approaches to the synthesis of terminal acetylenes from widely available aryl bromides rather than expensive iodides and using 4 or propiolic acid rather than TMS-acetylene as inexpensive alkyne sources are described.
\end{abstract}

\section{Introduction}

The Sonogashira coupling reaction of aryl or alkenyl halides with terminal acetylenes is the most straightforward method for the preparation of substituted alkynes [1-6], which are extensively used as building blocks in a great number of applications including the synthesis of pharmaceuticals [7-9], natural products and organic functional materials [10-13].
The Sonogashira coupling reaction is usually carried out under $\mathrm{Pd} / \mathrm{Cu}$ catalysis, in which the palladium has the function to promote the cross-coupling of an aryl fragment, added via oxidative addition of the corresponding halide, with an alkynyl residue to provide a disubstituted acetylene after reductive elimination. The activated acetylide species for the coupling process 
is generated from the reaction of a terminal alkyne with copper in the presence of a base and is transferred on the palladium site via transmetallation.

In order to improve the efficacy of the reaction, several variants have been introduced to perform efficiently this reaction with regard to synthetic and industrial aspects, including protocols in aqueous media [14-17], amine-free [18] or solvent-free conditions [19]. Moreover efficient reusable Pd catalysts [20-24] and even palladium-free methodologies [25-27] were developed. Copper-free reaction protocols [28-41] are highly promising for industrial applications as the presence of copper could lead to the formation of diyne byproducts, causing an irreversible loss of precious material, and complicates the recycling of the palladium catalyst since the two metals are difficult to separate.

Sonogashira reactions can be used for the syntheses of terminal alkynes from aryl halides through the coupling with an alkyne source such as trimethylsilylacetylene (TMSA) or 2-methyl-3butyn-2-ol (4) in presence of a $\mathrm{Cu} / \mathrm{Pd}$ bimetallic catalyst, followed by the basic cleavage of the protecting group [42-46] Terminal alkynes are often used as starting materials for the synthesis of disubstituted acetylenes through a second coupling process with another aryl halide.

Decarboxylative couplings have also been reported as an efficient synthetic tool for the synthesis of disubstituted alkynes. In fact, the use of propiolic acid as an alkyne source has opened new possibilities in the synthesis of acetylenic compounds, since many examples leading to diaryl- ( $\mathrm{sp}-\mathrm{sp}^{2}$ coupling), benzyl- ( $\mathrm{sp}-\mathrm{sp}^{3}$ coupling) and diaryl diacetylenes ( $\mathrm{sp}-\mathrm{sp}$ coupling) in addition to examples of carbon-heteroatom couplings have been reported in the recent literature [47-65]. The convenience in using propiolic acid as the alkyne source in the synthesis of symmetrical and unsymmetrical diarylacetylenes resides not only in its low cost, but also in the possibility to carry out a conventional and a decarboxylative Sonogashira coupling reaction in sequence at the two sp carbons with two different aryl halides. Therefore a disubstituted alkyne can be obtained in a one-pot protocol with a considerable reduction of synthetic and purification steps with respect to traditional procedures $[51,52,62]$. Instead, when looking to the preparation of terminal alkynes from propiolic acid derivatives, the $\mathrm{Cu}$-catalyzed protodecarboxylation of alkynoic acids $[67,68]$ or the Pd-catalyzed decarboxylation of allyl propiolates [69] have been reported, but these methods are limited to a narrow class of substrates and are not well suited for the preparation of aryl alkynes. More recently an optimized protocol for the synthesis of terminal arylalkynes from propiolic acid has been reported by Lee, in which the Pd-catalyzed coupling of propiolic acid with an aryl iodide is followed by the addition of the $\mathrm{Cu}$-catalyst, which promotes the protodecarboxylation of the arylpropiolic acid intermediate to the desired alkyne in good yields [70].

Acetylenic compounds and Sonogashira coupling reactions have found many applications in the synthesis of pharmaceutical substances. During the investigation about a possible alternative preparation of 2-methyl-4-(3-aminophenyl)-3-butyn-2-ol (2a) to improve a key-step in the synthesis of Erlotinib, an important anticancer pharmaceutical intermediate [71] and a promising anti-Alzheimer [72], we found that the $\mathrm{Pd} / \mathrm{Cu}-$ catalyzed Sonogashira coupling reaction of 3-bromoaniline (1a) with $\mathbf{4}$ is the actual industrial process for the synthesis of $\mathbf{2 a}$ in high yield [73-75] (Scheme 1).

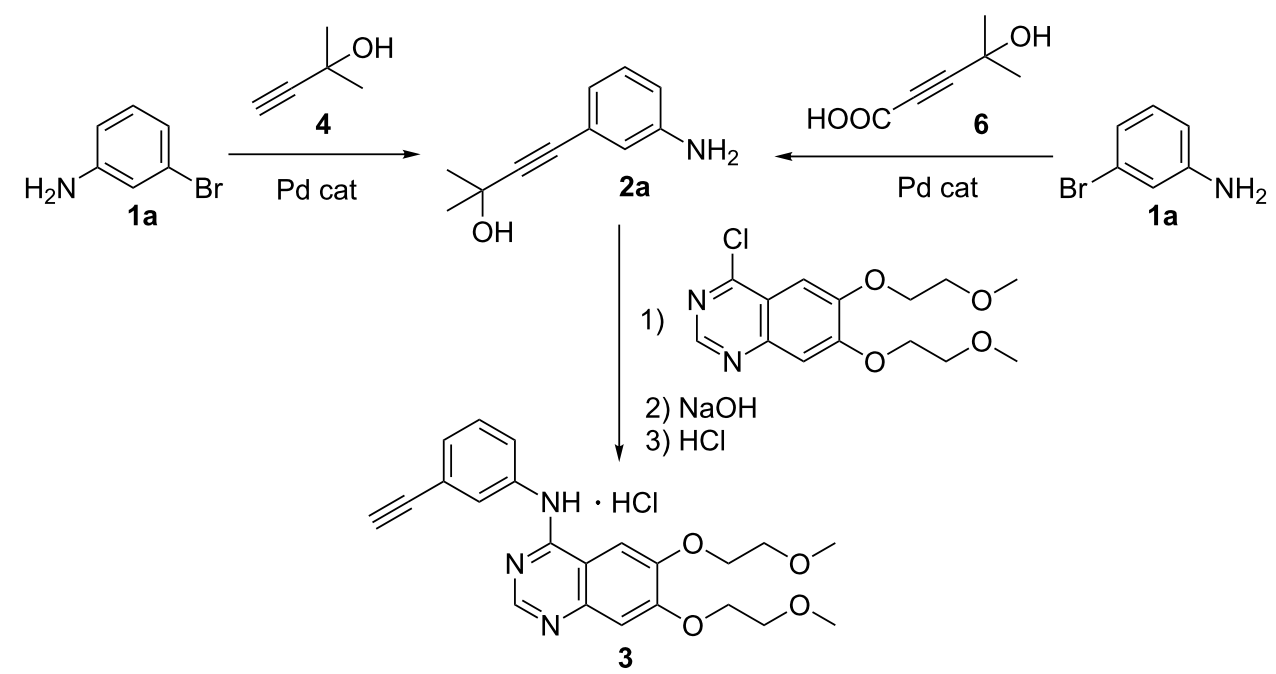

Scheme 1: Conventional (from the left) and decarboxylative (from the right) Pd-catalyzed Sonogashira coupling reactions for the preparation of 4-(3aminophenyl)-2-methyl-3-butin-2-ol (2a), which is used as an intermediate for the synthesis of Erlotinib hydrochloride (3). 
However, when the reaction is performed at industrial scale the presence of copper creates several problems in particular during the purification step. Moreover, the use of copper in Sonogashira reactions should be avoidable because of unwanted side homo-couplings of the acetylenic substrate, causing an irreversible loss of precious starting material. Therefore, the Pd-catalyzed coupling reaction of $\mathbf{4}$ or a propiolic acid derivative with 3-bromoaniline, in order to approach the synthesis of 3-aminophenylacetylene without the use of copper, would be highly desiderable [76].

Although many examples of copper-free Sonogashira reactions between aryl halides and terminal alkynes for the synthesis of disubstituted acetylenes have been reported in the literature [9], few specific protocols for 4 were presented [77-79]. Successful copper free synthesis of 4-aryl-2-methyl-3-butyn-2-ols from aryl bromides have been performed by carrying out the reaction in piperidine as the solvent $[39,78]$ or by using aminophosphines [18] as well as phenanthryl imidazolium carbenes as the catalyst ligands [79]. A more practical methodology has been reported by Shirakawa in which a $\mathrm{Pd}(\mathrm{OAc})_{2} / \mathrm{PPh}_{3}$ catalyst system in DMSO and in the presence of $\mathrm{K}_{3} \mathrm{PO}_{4}$ as the base was able to couple aryl bromides with terminal alkynes, including a couple of examples with 2-methyl-3-butyn-2-ol, in moderate yield [35]. Two simple reaction protocols for the copper-free coupling of $\mathbf{4}$ have been also reported for iodo nitroxides [30] and cyclopropyl iodides [29].

Herein, we present two practical and very efficient synthetic methods for the preparation of aryl-2-methyl-3-butyn-2-ols from aryl bromides via Pd-catalyzed conventional and decarboxylative coupling reactions by using 4 or 4-hydroxy-4methyl-2-pentynoic acid as the alkyne sources and without the use of copper. These methods have been optimized for the synthesis of 2-methyl-4-(3-aminophenyl)-3-butyn-2-ol, which has never been prepared through a $\mathrm{Cu}$-free coupling process and which is also a pharmaceutical intermediate for Erlotinib.

The present work provides also a more detailed description about the coupling process and a more extended rection scope that was not included in a previous patent application by our group, in which the decarboxylative coupling reaction for the synthesis of intermediate 2a has been firstly described [76].

\section{Results and Discussion}

In order to perform efficiently the palladium-catalyzed coupling reaction between 3-bromoaniline (1a) and $\mathbf{4}$ to give 2-methyl-4(3-aminophenyl)-3-butyn-2-ol (2a) (Table 1), we screened different bases, solvents and ligands in the absence of copper. We firstly examined the coupling reaction using a catalytic system based on palladium acetate and triphenylphosphine in presence of TBAF (tetrabutylammonium fluoride) as the base. After using different solvents, we found that THF provided the best results with regard to toluene and more polar media such as DMF, affording the product in $61 \%$ yield (Table 1 , entries $1-3$ ). The use of inorganic bases as well as common organic amines, typically employed in conventional $\mathrm{Pd} / \mathrm{Cu}$ Sonogashira coupling protocols, resulted in poor yields of our desired product (Table 1, entries 4-6). Piperidine, which has been reported to efficiently perform copper-free coupling reactions of $\mathbf{4}$ with polycyclic aryl bromides [77], gave only $17 \%$ yield with our substrate (Table 1, entry 6). Instead, a decisive increase of the yield was observed by replacing TBAF with DBU, which furnished product $2 \mathrm{a}$ in $84 \%$ yield (Table 1, entry 7). A further improvement was found by modifying the catalyst with different ligands (Table 1, entries 7-11). In fact, changing of $\mathrm{PPh}_{3}$ with $\mathrm{P}(p \text {-tol })_{3}$ allowed to obtain 2a in $89 \%$ yield (Table 1, entry 9), whereas other monodentate or chelating phosphines displayed a lower efficiency. $\mathrm{Pd}$ sources other than $\mathrm{Pd}(\mathrm{OAc})_{2}$ were also used but did not show positive effects.

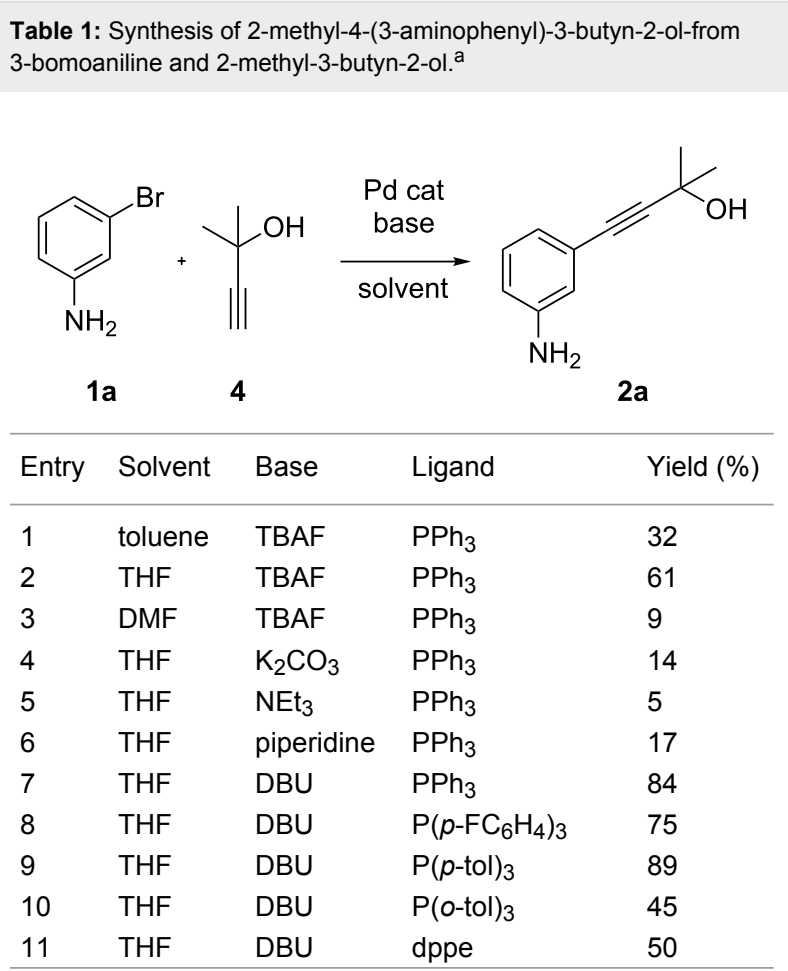

aReaction conditions: 1a (1.0 mmol), 4 (1.2 mmol), $\mathrm{Pd}(\mathrm{OAc})_{2}$ $(0.03 \mathrm{mmol})$, ligand ( $6 \mathrm{~mol} \%)$, base (3 equiv), $6 \mathrm{~h}, 80^{\circ} \mathrm{C}$. Yields were determined by GC using tetradecane as an internal standard.

Having thus found an optimized method for the cooper free palladium-catalyzed coupling of 3-bromoaniline (1a) with 2-methylbut-3-yn-2-ol (4), we next examined wherever this protocol could be applied to a more general class of substrates. 
As stated in Table 2, good to excellent yields were obtained by using different aryl bromides including electron-rich, electronpoor, sterically crowded and heterocyclic derivatives. Moreover, the coupling reaction seems to be very efficient and selective with regard to different functional groups placed on the aryl bromide, including acetamido, dimethylamino, methoxy, chloro, fluoro, trifluoromethyl, nitro, methoxycarbonyl and cyano groups. Bromonaphthalene (1j) and 3-bromopyridine (1n) reacted smoothly.
Bromobenzenes bearing a methyl groups in the ortho, meta and para positions gave the corresponding products in similar good yields. Thus, the reaction can be applied to a wide substrate range witnessing the attractiveness and the generality of this protocol. It is also worth noting that these conditions are also highly practical and well suited to scale-up the reaction, since inexpensive $\mathbf{4}$ can be efficiently coupled with aryl bromides instead of iodides by using common solvents and ligands for the palladium catalyst.

Table 2: Copper-free palladium-catalyzed coupling of 2-methylbut-3-yn-2-ol (4) with aryl bromides. ${ }^{\text {a }}$

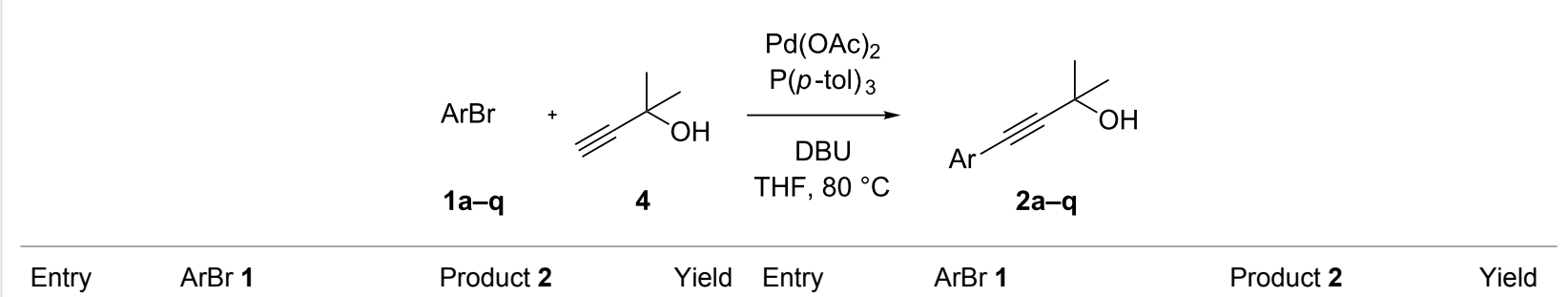

1<smiles>Nc1cccc(Br)c1</smiles>

$1 \mathrm{a}$<smiles>CC(C)(O)C#Cc1cccc(N)c1</smiles>

$2 a$<smiles>CC(C)(O)C#Cc1cccc(N)c1</smiles>

$2 b$<smiles>CN(C)c1ccc(C#CC(C)(C)O)cc1</smiles>

2c<smiles>COc1cc(C#CC(C)(C)O)cc(OC)c1</smiles>

2d

5<smiles>COc1ccc(Br)cc1</smiles><smiles>COc1ccc(C#CC(C)(C)O)cc1</smiles>

86

10<smiles>Brc1cccc2ccccc12</smiles>

1j

95

11<smiles>Clc1cccc(Br)c1</smiles>

$1 \mathrm{k}$<smiles>Fc1ccc(Br)cc1</smiles><smiles>FC(F)(F)c1ccc(Br)cc1</smiles><smiles>Brc1cccnc1</smiles><smiles>CC(C)(O)C#Cc1cccc2ccccc12</smiles>

2j<smiles>CC(C)(O)C#Cc1cccc(Cl)c1</smiles>

2k<smiles>CC(C)(O)C#Cc1ccc(F)cc1</smiles>

21<smiles>CC(C)(O)C#Cc1ccc(C(F)(F)F)cc1</smiles>

$2 \mathrm{~m}$<smiles>CC(C)(O)C#Cc1cccnc1</smiles>

95 
Table 2: Copper-free palladium-catalyzed coupling of 2-methylbut-3-yn-2-ol (4) with aryl bromides. ${ }^{\text {a }}$ (continued)

6<smiles>Cc1ccccc1Br</smiles><smiles>Cc1cccc(Br)c1</smiles>

$1 \mathrm{~g}$<smiles>CCC(C)(O)C#Cc1ccccc1Cl</smiles><smiles>Cc1cccc(C#CC(C)(C)O)c1</smiles>

$2 \mathrm{~g}$

8<smiles>Cc1ccc(Br)cc1</smiles>

$1 \mathrm{~h}$<smiles>Cc1ccc(C#CC(C)(C)O)cc1</smiles>

$2 \mathrm{~h}$

9<smiles>Brc1ccccc1</smiles>

$1 \mathrm{i}$<smiles>CC(C)(O)C#Cc1ccccc1</smiles>

80 15<smiles>O=[N+]([O-])c1cccc(Br)c1</smiles>

89 16<smiles>COC(=O)c1ccc(Br)cc1</smiles>
87 17<smiles>N#Cc1ccc(Br)cc1</smiles><smiles>CC(C)(O)C#Cc1cccc([N+](=O)[O-])c1</smiles>

77

20<smiles>COC(=O)c1ccc(C#CC(C)(C)O)cc1</smiles>

72<smiles>CC(C)(O)C#Cc1ccc(C#N)cc1</smiles>

aReaction conditions: 1a-q (1.0 mmol), 2-methylbut-3-yn-2-ol (4) $(1.2 \mathrm{mmol}), \mathrm{Pd}(\mathrm{OAc})_{2}(3 \mathrm{~mol} \%), \mathrm{P}(p \text {-tol })_{3}(6 \mathrm{~mol} \%), \mathrm{DBU}(3 \mathrm{mmol}), 80{ }^{\circ} \mathrm{C}, 6 \mathrm{~h}$ Yields refer to isolated products.

The copper-free synthesis of 4-aryl-2-methyl-3-butyn-2-ols was also approached through a decarboxylative coupling reaction in which a derivative of propiolic acid (5) was used as the alkyne source. In order to prevent the possible double coupling process due to the high reactivity of the terminal $\mathrm{C}(\mathrm{sp})-\mathrm{H}$, the protection of the acetylenic proton of $\mathbf{5}$ was necessary. Analogously to acetylene $[80,81]$, the protection of propiolic acid with acetone was carried out in presence of an excess of $\mathrm{KOH}$ (6.0 equiv) at room temperature (Scheme 2).

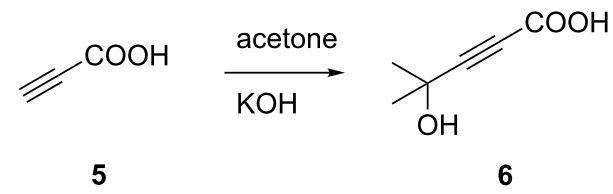

Scheme 2: Protection of propiolic acid with acetone.

The screening of the optimal palladium catalyst for the Pd-catalyzed coupling reaction of 3-bromoaniline with 4-hydroxy-4-methyl-2-pentynoic acid (6) was studied by using different bases, ligands and Pd sources (Table 3 ). In accordance with the reported data, tetrabutylammonium fluoride (TBAF) $[64,66]$ was found to be able to promote the decarboxylative coupling at $80{ }^{\circ} \mathrm{C}$ (Table 3, entry 5) whereas $\mathrm{Cs}_{2} \mathrm{CO}_{3}$ [63], $\mathrm{CsF}$ or organic amines were less effective in promoting this reaction (Table 3, entries 1-4).

The use of bulky electron-rich biarylphosphines as ligands for the palladium catalyst seems also to play a crucial role in promoting the coupling reaction. In fact, SPhos (Table 3, entry 5) resulted the best ligand with respect to XPhos (Table 3, entry 7), whereas other simple monodentate phosphines, such as $\mathrm{P} t-\mathrm{Bu}_{3}$ or $\mathrm{PPh}_{3}$, seem not to be able to promote efficiently the reaction (data not shown). The change of the $\mathrm{Pd}$ source to $\mathrm{Pd}_{2}(\mathrm{dba})_{3}$ led to a further increase of the yield up to $89 \%$ (Table 3, entry 8), while other precursors decreased the performances of the system. Concerning the solvent media, similar yields were obtained using THF or NMP (Table 3, entries 5 and 6 ), but when toluene or dioxane were used, the yields were not satisfactory.

With an optimized system for the coupling of $\mathbf{6}$ with $m$-bromoaniline in hand, we next investigated the scope of the reaction (Table 4). 
Table 3: Palladium-catalyzed coupling reaction of 4-hydroxy-4-methyl-2-pentynoic acid and $m$-bromoaniline. ${ }^{\text {a }}$<smiles>Nc1cccc(Br)c1</smiles>

$1 \mathrm{a}$<smiles>CC(C)(O)C#CC(=O)O</smiles>

6

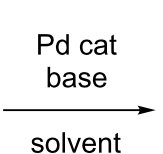

solvent<smiles>CC(C)(O)C#Cc1cccc(N)c1</smiles>

$2 \mathbf{a}$<smiles>COc1cccc(OC)c1-c1ccccc1POCCO</smiles><smiles>CC(C)c1cc(C(C)C)c(-c2cccc(C(F)(F)F)c2)c(C(F)(F)F)c1</smiles>

\begin{tabular}{llllll}
\hline Entry & Solvent & Base & $\mathrm{Pd}$ & Ligand & Yield (\%) \\
\hline 1 & THF & $\mathrm{Cs}_{2} \mathrm{CO}_{3}$ & $\mathrm{Pd}(\mathrm{OAc})_{2}$ & SPhos & 5 \\
2 & $\mathrm{CsF}$ & $\mathrm{Pd}(\mathrm{OAc})_{2}$ & SPhos & 7 \\
3 & $\mathrm{NHF}$ & $\mathrm{NH}(\mathrm{iPr})_{2}$ & $\mathrm{Pd}(\mathrm{OAc})_{2}$ & SPhos & 4 \\
4 & $\mathrm{THF}$ & $\mathrm{Pd}(\mathrm{OAc})_{2}$ & SPhos & 42 \\
5 & $\mathrm{THF}$ & $\mathrm{Pd}(\mathrm{OAc})_{2}$ & SPhos & 80 \\
6 & $\mathrm{THAF}$ & $\mathrm{Pd}(\mathrm{OAc})_{2}$ & SPhos & 76 \\
7 & $\mathrm{THF}$ & $\mathrm{Pd}(\mathrm{OAc})_{2}$ & XPhos & 55 \\
8 & $\mathrm{THP}$ & $\mathrm{TBAF}$ & $\mathrm{Pd}(\mathrm{dba})_{3}$ & SPhos & 89 \\
9 & THF & TBAF & $(\mathrm{PdallylCl})_{2}$ & SPhos & 79
\end{tabular}

aReaction conditions: $1 \mathrm{a}(0.5 \mathrm{mmol}), 6(0.63 \mathrm{mmol}), \mathrm{Pd}$ source $(5 \mathrm{~mol} \%)$, ligand $(7.5 \mathrm{~mol} \%)$, base $\left(3\right.$ equiv), $14 \mathrm{~h}, 80^{\circ} \mathrm{C}$. Yields were determined by GC using tetradecane as an internal standard.

Table 4: Palladium catalyzed coupling of 4-hydroxy-4-methyl-2-pentynoic acid (6) with aryl bromides. ${ }^{a}$

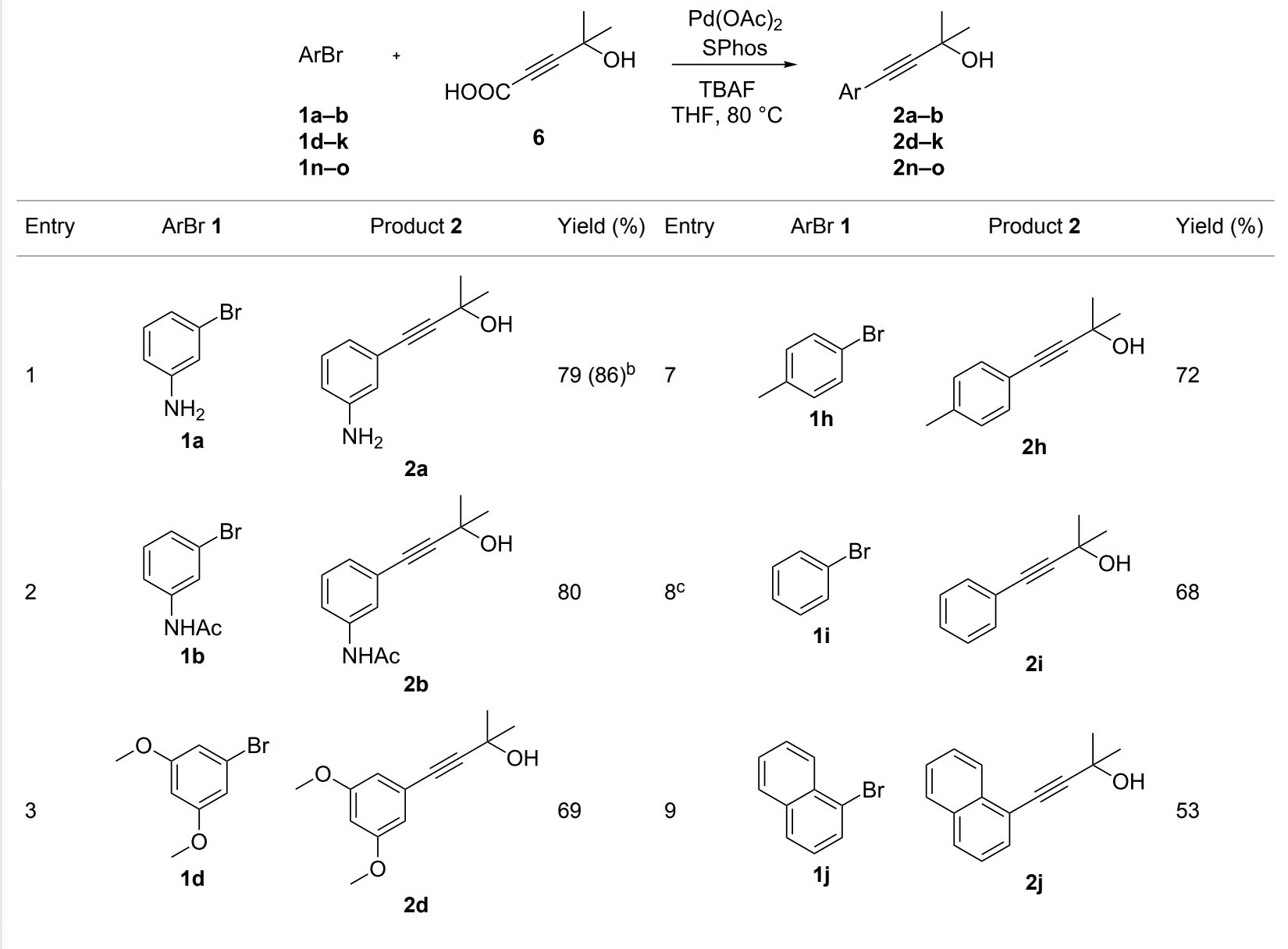


Table 4: Palladium catalyzed coupling of 4-hydroxy-4-methyl-2-pentynoic acid (6) with aryl bromides. ${ }^{\text {a }}$ (continued)

4<smiles>COc1ccc(Br)cc1</smiles>

1e<smiles>Cc1ccccc1Br</smiles>

$1 \mathrm{f}$

6<smiles>Cc1cccc(Br)c1</smiles><smiles>COc1ccc(C#CC(C)(C)O)cc1</smiles>

$2 e$<smiles>[Z7]c1ccccc1C#CC(C)(C)O</smiles><smiles>Cc1cccc(C#CC(C)(C)O)c1</smiles>

$2 g$
56 $10^{c}$<smiles>Clc1cccc(Br)c1</smiles>

$1 \mathrm{k}$

78<smiles>Brc1cccnc1</smiles>

$12^{c}$<smiles>CC(C)(O)C#Cc1cccc(Cl)c1</smiles><smiles>CC(C)(O)C#Cc1cccnc1</smiles><smiles>O=[N+]([O-])c1cccc(Br)c1</smiles>

10 2k

$2 n$

25

61

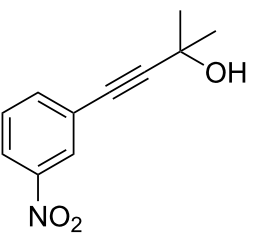

aReaction conditions: 1 (0.5 mmol), 4-hydroxy-4-methyl-2-pentynoic acid (6) (0.63 mmol), $\mathrm{Pd}(\mathrm{OAc})_{2}(5 \mathrm{~mol} \%)$, SPhos (7.5 mol \%), TBAF·3H $\mathrm{O}_{2}$ $(1.5 \mathrm{mmol}), 80^{\circ} \mathrm{C}, 14 \mathrm{~h}$. Yields refer to isolated products. ${ }^{\mathrm{b}} \mathrm{Pd}_{2}(\mathrm{dba})_{3}$ was used instead of $\mathrm{Pd}(\mathrm{OAc})_{2} .{ }^{c} 4-\mathrm{Hydroxy}-4-\mathrm{methyl}-2$-pentynoic acid $(1 \mathrm{mmol})$ and XPhos instead of SPhos were used.

A variety of aryl bromides bearing electron-rich, electronneutral and electron-poor substituents were coupled with 4-hydroxy-4-methyl-2-pentynoic acid (6) affording the corresponding products in good yields. As can be seen from the examples listed in Table 4 several functional groups were tolerated including acetamido, methoxy and nitro groups. The reaction has been applied also to heterocyclic and polycyclic aryl bromides.

A little modification with respect to 3-bromoaniline (1a) was necessary in order to successfully apply the protocol to all substrates used for the synthesis of 4-aryl-2-methyl-3-butyn-2ols through the decarboxylative coupling approach. In fact, electron rich aryl bromides reacted smoothly with $\mathbf{6}$ when using a system containing $\mathrm{Pd}(\mathrm{OAc})_{2} / \mathrm{SPhos}$ as the catalyst [82], TBAF as the base in THF as solvent. The corresponding alkynes were therefore obtained in good yields (60-80\% range), especially for those substrates bearing methyl, methoxy and amino groups (Table 4, entries 1-8). However, in the case of bromobenzene and aryl bromides bearing electron withdrawing groups, the corresponding products were obtained with satisfactory yields only when using 2 equiv of 4 with respect to the substrate and replacing SPhos with XPhos as ligand for the palladium catalyst (Table 4, entries 9-12). In these cases we observed also the formation of the symmetrical diarylacetylene as byproduct derived from the starting aryl bromides in a $2-5 \%$ yield range. Likely, the acetone protecting group is cleaved from protected terminal alkyne even under such mild conditions and therefore, the terminal alkyne generated in situ couples with another molecule of the starting aryl bromide to provide the symmetrical acetylene.

Finally, it is worth noting that the preparation of product 2a has been also reported through the acid hydrolysis of the acetamido group of $\mathbf{2 b}$ or by the reduction of the nitro group of $\mathbf{2 0}$ [76], however the direct coupling of 3-bromoaniline with 4 or 6 clearly remains the most efficient approach to the synthesis of 3-ethynylaniline.

\section{Conclusion}

Two simple and efficient protocols for the preparation of aryl-2methyl-3-butyn-2-ols from aryl bromides, which are inexpensive intermediates for the preparation of terminal alkynes, have been described. A copper-free, palladium catalyst generated from $\mathrm{Pd}(\mathrm{OAc})_{2}$ and $\mathrm{P}(p \text {-tol })_{3}$ allowed the coupling of aryl bromides with 4 in THF. The use of DBU as the base seems to play a crucial role to efficiently perform this coupling reaction on a wide scope of substrates without the use of copper. Moreover, the palladium-catalyzed decarboxylative coupling reaction of 4-hydroxy-4-methyl-2-pentynoic acid with aryl bromides for the preparation of aryl-2-methyl-3-butyn-2-ols has been investigated. The decarboxylative coupling was carried out by using a catalyst generated in situ from $\mathrm{Pd}(\mathrm{OAc})_{2}$ and a bulky electronrich phospine, such as SPhos or XPhos, in THF as the solvent 
and in presence of TBAF as the base. By approaching the synthesis of aryl-2-methyl-3-butyn-2-ols through decarboxylative coupling reactions of 4-hydroxy-4-methyl-2-pentynoic acid, we found a good compatibility with differently substituted aryl bromides.

\section{Experimental}

All reactions, if not stated otherwise, were performed in ovendried glassware under an argon atmosphere containing a tefloncoated stirring bar and a dry septum. Chemicals and solvents were either purchased (puriss. p.a.) from commercial suppliers or purified by standard techniques. All reactions were monitored by GC using tetradecane as an internal standard. Response factors of the products with regard to tetradecane were obtained experimentally by analyzing known quantities of the substances. GC analyses were carried out using an HP-5 capillary column (phenyl methyl siloxane, $30 \mathrm{~m} \times 320 \times 0.25,100 /$ 2.3-30-300/3, 2 min at $50{ }^{\circ} \mathrm{C}$, heating rate $25^{\circ} \mathrm{C} / \mathrm{min}, 3 \mathrm{~min}$ at $250{ }^{\circ} \mathrm{C}$ ). Column chromatography was performed with 230-400 mesh silica-gel. NMR spectra were obtained on a Bruker AVANCE 300 spectrometer $(300 \mathrm{MHz})$ using $\mathrm{CDCl}_{3}$ as solvent, $300 \mathrm{MHz}$ and $75 \mathrm{MHz}$, respectively. Mass spectral data were acquired on a Trace GC-MS 2000 ThermoQuest. Melting points were measured on a Büchi 535 .

\section{General procedure for the preparation of arylalkynes $\mathbf{2 a - q}$ (method A)}

An oven-dried $20 \mathrm{~mL}$ Schlenk tube equipped with a magnetic stirring bar and a rubber septum was charged with $\mathrm{Pd}(\mathrm{OAc})_{2}$ $(6.7 \mathrm{mg}, 30 \mu \mathrm{mol})$ and tri( $p$-tolyl)phosphine $(18.2 \mathrm{mg}$, $60 \mu \mathrm{mol})$. After purging the vessel with alternating vacuum and nitrogen cycles, degassed THF ( $3 \mathrm{~mL}), 1,8$-diazabicycloundec7-ene $(450 \mu \mathrm{L}, 3.0 \mathrm{mmol}), 2$-methylbut-3-yn-2-ol $(120 \mu \mathrm{L}$, $1.24 \mathrm{mmol})$ and aryl bromides $\mathbf{1 a}-\mathbf{q}(1 \mathrm{mmol})$ were added via syringe (solid aryl bromides were added as solution in degassed THF) and the mixture was stirred at $80^{\circ} \mathrm{C}$ for $6 \mathrm{~h}$. After cooling to $\mathrm{rt}$ the mixture was diluted with water $(20 \mathrm{~mL})$ and extracted with AcOEt $(3 \times 20 \mathrm{~mL})$. The combined organic extracts were washed with $\mathrm{H}_{2} \mathrm{O}(20 \mathrm{~mL})$, saturated aqueous $\mathrm{NaCl}(20 \mathrm{~mL})$, dried over $\mathrm{MgSO}_{4}$ and concentrated in vacuum. The crude product was purified by silica gel chromatography (eluant hexane/Et ${ }_{2} \mathrm{O}$ gradient) affording the corresponding products $\mathbf{2 a}-\mathbf{q}$.

\section{General procedure for the preparation of arylalkynes $\mathbf{2 a}, \mathbf{b}, \mathbf{2} \mathbf{d}-\mathbf{h}$ and $\mathbf{2 j}$ (method B)}

An oven-dried $20 \mathrm{~mL}$ Schlenk tube equipped with a magnetic stirring bar and a rubber septum was charged with $\mathrm{Pd}(\mathrm{OAc})_{2}$ (5.6 mg, $25 \mu \mathrm{mol})$, 2-dicyclohexylphosphino-2',6'-dimethoxybiphenyl (15.4 mg, $37.5 \mu \mathrm{mol})$ and 4-hydroxy-4-methyl-2pentynoic acid $(6,80 \mathrm{mg}, 0.63 \mathrm{mmol})$. After purging the vessel with alternating vacuum and nitrogen cycles, a degassed solution of TBAF $3 \mathrm{H}_{2} \mathrm{O}(0.47 \mathrm{~g}, 1.5 \mathrm{mmol})$ in THF $(3 \mathrm{~mL})$ was added. Aryl bromides $\mathbf{1 a}, \mathbf{b}, \mathbf{1 d}-\mathbf{h}$ and $\mathbf{1 j}(0.5 \mathrm{mmol})$ were added via syringe (solid aryl bromides were added as solution in degassed THF) and the mixture was stirred at $80{ }^{\circ} \mathrm{C}$ for $14 \mathrm{~h}$. After cooling to $\mathrm{rt}$ the mixture was diluted with water $(20 \mathrm{~mL})$ and extracted with AcOEt $(3 \times 20 \mathrm{~mL})$. The combined organic extracts were washed with $\mathrm{H}_{2} \mathrm{O}(20 \mathrm{~mL})$, saturated aqueous $\mathrm{NaCl}(20 \mathrm{~mL})$, dried over $\mathrm{MgSO}_{4}$ and concentrated in vacuum. The crude product was purified by silica gel chromatography (eluant cyclohexane $/ \mathrm{Et}_{2} \mathrm{O}$ or EtOAc gradient) affording the corresponding products $\mathbf{2} \mathbf{a}, \mathbf{b}, \mathbf{2 d}-\mathbf{h}$ and $\mathbf{2} \mathbf{j}$.

\section{General procedure for the preparation of arylalkynes $\mathbf{2 i}, \mathbf{2 k}, \mathbf{2 n}$ and $\mathbf{2 0}$ (method C)}

An oven-dried $20 \mathrm{~mL}$ Schlenk tube equipped with a magnetic stirring bar and a rubber septum was charged with $\mathrm{Pd}(\mathrm{OAc})_{2}$ (5.6 mg, $25 \mu \mathrm{mol}$ ), 2-Dicyclohexylphosphino-2',4',6'-triisopropylbiphenyl (17.9 mg, $37.5 \mu \mathrm{mol})$, and 4-hydroxy-4-methyl2-pentynoic acid $(6,128 \mathrm{mg}, 1.00 \mathrm{mmol})$. After purging the vessel with alternating vacuum and nitrogen cycles, a degassed solution of TBAF $3 \mathrm{H}_{2} \mathrm{O}(0.47 \mathrm{~g}, 1.5 \mathrm{mmol})$ in THF $(3 \mathrm{~mL})$ was added. Aryl bromides 1i, $1 \mathbf{k}, \mathbf{1 n}$ and $\mathbf{1 0}(0.5 \mathrm{mmol})$ were added via a syringe (solid aryl bromides were added as solution in degassed THF) and the mixture was stirred at $80{ }^{\circ} \mathrm{C}$ for $14 \mathrm{~h}$. After cooling to $\mathrm{rt}$ the mixture was diluted with water $(20 \mathrm{~mL})$ and extracted with AcOEt $(3 \times 20 \mathrm{~mL})$. Combined organic extracts were washed with $\mathrm{H}_{2} \mathrm{O}(20 \mathrm{~mL})$, saturated aqueous $\mathrm{NaCl}(20 \mathrm{~mL})$, dried over $\mathrm{MgSO}_{4}$ and concentrated in vacuum. The crude product was purified by silica gel chromatography (eluant cyclohexane $/ \mathrm{Et}_{2} \mathrm{O}$ or EtOAc gradient) affording the corresponding products $\mathbf{2 i}, \mathbf{2 k}, \mathbf{2 n}$ and $\mathbf{2 0}$.

\section{Supporting Information}

\section{Supporting Information File 1}

Description of all procedures and characterization data of all new compounds.

[http://www.beilstein-journals.org/bjoc/content/ supplementary/1860-5397-10-36-S1.pdf]

\section{Acknowledgements}

We gratefully acknowledge MIUR (Rome) within the national PRIN framework and FIS for financial support and for the generous donation of precious materials.

\section{References}

1. Chinchilla, R.; Nájera, C. Chem. Rev. 2007, 107, 874-922. doi:10.1021/cr050992x 
2. Doucet, H.; Hierso, J.-C. Angew. Chem., Int. Ed. 2007, 46, 834-871. doi:10.1002/anie.200602761

3. Negishi, E.-i.; Anastasia, L. Chem. Rev. 2003, 103, 1979-2018. doi:10.1021/cr020377i

4. Tykwinski, R. R. Angew. Chem., Int. Ed. 2003, 42, 1566-1568. doi:10.1002/anie.200201617

5. Cassar, L. J. Organomet. Chem. 1975, 93, 253-257. doi:10.1016/S0022-328X(00)94048-8

6. Sonogashira, K.; Tohda, Y.; Hagihara, N. Tetrahedron Lett. 1975, 16, 4467-4470. doi:10.1016/S0040-4039(00)91094-3

7. Rakshit, S.; Patureau, F. W.; Glorius, F. J. Am. Chem. Soc. 2010, 132, 9585-9587. doi:10.1021/ja104305s

8. Falcone, D.; Li, J.; Kale, A.; Jones, G. B. Bioorg. Med. Chem. Lett. 2008, 18, 934-937. doi:10.1016/j.bmcl.2007.12.045

9. Nicolaou, K. C.; Zipkin, R. E.; Dolle, R. E.; Harris, B. D. J. Am. Chem. Soc. 1984, 106, 3548-3551. doi:10.1021/ja00324a024

10. Liu, J.; Lam, J. W. Y.; Tang, B. Z. Chem. Rev. 2009, 109, 5799-5867. doi:10.1021/cr900149d

11. Moon, J. H.; McDaniel, W.; MacLean, P.; Hancock, L. F. Angew. Chem., Int. Ed. 2007, 46, 8223-8225. doi:10.1002/anie.200701991

12. Kim, T.-H.; Swager, T. M. Angew. Chem., Int. Ed. 2003, 42, 4803-4806. doi:10.1002/anie.200352075

13. McQuade, D. T.; Pullen, A. E.; Swager, T. M. Chem. Rev. 2000, 100, 2537-2574. doi:10.1021/cr9801014

14. Lipshutz, B. H.; Chung, D. W.; Rich, B. Org. Lett. 2008, 10, 3793-3796. doi:10.1021/ol801471f

15. Shi, S.; Zhang, Y. Synlett 2007, 1843-1850. doi:10.1055/s-2007-984533

16. Liang, B.; Dai, M.; Chen, J.; Yang, Z. J. Org. Chem. 2005, 70, 391-393. doi:10.1021/jo048599z

17. Wolf, C.; Lerebours, R. Org. Biomol. Chem. 2004, 2, 2161-2164. doi:10.1039/b407773c

18. Cheng, J.; Sun, Y.; Wang, F.; Guo, M.; Xu, J.-H.; Pan, Y.; Zhang, Z. J. Org. Chem. 2004, 69, 5428-5432. doi:10.1021/jo049379o

19. Kabalka, G. W.; Wang, L.; Namboodiri, V.; Pagni, R. M. Tetrahedron Lett. 2000, 41, 5151-5154. doi:10.1016/S0040-4039(00)00774-7

20. Polshettiwara, V.; Len, C.; Fihri, A. Coord. Chem. Rev. 2009, 253 , 2599-2626. doi:10.1016/j.ccr.2009.06.001

21. Cai, M.; Sha, J.; Xu, Q. Tetrahedron 2007, 63, 4642-4647. doi:10.1016/j.tet.2007.03.111

22. Corma, A.; García, H.; Leyva, A. Tetrahedron 2005, 61, 9848-9854. doi:10.1016/j.tet.2005.06.119

23. Remmele, H.; Köllhofer, A.; Plenio, H. Organometallics 2003, 22, 4098-4103. doi:10.1021/om030450a

24. Choudary, B. M.; Madhi, S.; Chowdari, N. S.; Kantam, M. L.; Sreedhar, B. J. Am. Chem. Soc. 2002, 124, 14127-14136. doi:10.1021/ja026975w

25. Chen, H.-J.; Lin, Z.-Y.; Li, M.-Y.; Lian, R.-J.; Xue, Q.-W.; Chung, J.-L.; Chen, S.-C.; Chen, Y.-J. Tetrahedron 2010, 66, 7755-7761. doi:10.1016/j.tet.2010.07.072

26. Monnier, F.; Turtaut, F.; Duroure, L.; Taillefer, M. Org. Lett. 2008, 10, 3203-3206. doi:10.1021/ol801025u

27. Thathagar, M. B.; Beckers, J.; Rothenberg, G. Green Chem. 2004, 6, 215-218. doi:10.1039/b401586j

28. Pu, X.; Li, H.; Colacot, T. J. J. Org. Chem. 2013, 78, 568-581. doi:10.1021/jo302195y
29. de Carné-Carnavalet, B.; Archambeau, A.; Meyer, C.; Cossy, J.; Folléas, B.; Brayer, J.-L.; Demoute, J.-P. Org. Lett. 2011, 13, 956-959. doi:10.1021/ol1029996

30. Keddie, D. J.; Fairfull-Smith, K. E.; Bottle, S. E. Org. Biomol. Chem. 2008, 6, 3135-3143. doi:10.1039/b806963h

31. Guan, J. T.; Weng, T. Q.; Yu, G.-A.; Liu, S. H. Tetrahedron Lett. 2007, 48, 7129-7133. doi:10.1016/j.tetlet.2007.07.207

32. Kawanami, H.; Matsushima, K.; Sato, M.; Ikushima, Y. Angew. Chem., Int. Ed. 2007, 46, 5129-5132. doi:10.1002/anie.200700611

33. Ruiz, J.; Cutillas, N.; López, F.; López, G.; Bautista, D. Organometallics 2006, 25, 5768-5773. doi:10.1021/om060636k

34. Liang, Y.; Xie, Y.-X.; Li, J.-H. J. Org. Chem. 2006, 71, 379-381. doi:10.1021/j0051882t

35. Shirakawa, E.; Kitabata, T.; Otsukaa, H.; Tsuchimoto, T. Tetrahedron 2005, 61, 9878-9885. doi:10.1016/j.tet.2005.07.099

36. Bandini, M.; Luque, R.; Budarin, V.; Macquarrie, D. J. Tetrahedron 2005, 61, 9860-9868. doi:10.1016/j.tet.2005.06.082

37. Urgaonkar, S.; Verkade, J. G. J. Org. Chem. 2004, 69, 5752-5755. doi:10.1021/jo049325e

38. Méry, D.; Heuzé, K.; Astruc, D. Chem. Commun. 2003, 1934-1935. doi:10.1039/b305391c

39. Soheili, A.; Albaneze-Walker, J.; Murry, J. A.; Dormer, P. G.; Hughes, D. L. Org. Lett. 2003, 5, 4191-4194. doi:10.1021/ol035632f

40. Fukuyama, T.; Shinmen, M.; Nishitani, S.; Sato, M.; Ryu, I. Org. Lett. 2002, 4, 1691-1694. doi:10.1021/ol0257732

41. Böhm, V. P. W.; Hermann, W. A. Eur. J. Org. Chem. 2000, 3679-3681. doi:10.1002/1099-0690(200011)2000:22<3679::AID-EJOC3679>3.0.C $\mathrm{O} ; 2-\mathrm{X}$

42. Nagy, A.; Novák, Z.; Kotschy, A. J. Organomet. Chem. 2005, 690, 4453-4461. doi:10.1016/j.jorganchem.2004.12.036

43. Mio, M. J.; Kopel, L. C.; Braun, J. B.; Gadzikwa, T. L.; Hull, K. L.; Brisbois, R. G.; Markworth, C. J.; Grieco, P. A. Org. Lett. 2002, 4, 3199-3202. doi:10.1021/ol026266n

44. Holmes, A. B.; Sporikou, C. N. Org. Synth. 1993, 8, 606-610.

45. Csékei, M.; Novák, Z.; Kotschy, A. Tetrahedron 2008, 64, 8992-8996. doi:10.1016/j.tet.2008.05.100

46. Novák, Z.; Nemes, P.; Kotschy, A. Org. Lett. 2004, 6, 4917-4920. doi:10.1021/ol047983f

47. Reddy, P. V.; Srinivas, P.; Annapurna, M.; Bhargava, S.; Wagler, J.; Mirzadeh, N.; Kantam, M. L. Adv. Synth. Catal. 2013, 355, 705-710. doi:10.1002/adsc.201200876

48. Li, X.; Yang, F.; Wu, Y. J. Org. Chem. 2013, 78, 4543-4550. doi:10.1021/j0400574d

49. Huang, Z.; Shang, R.; Zhang, Z.-R.; Tan, X.-D.; Xiao, X.; Fu, Y. J. Org. Chem. 2013, 78, 4551-4557. doi:10.1021/jo400616r

50. Zhao, B. Org. Biomol. Chem. 2012, 10, 7108-7119. doi:10.1039/c2ob25643f

51. Tartaggia, S.; De Lucchi, O.; Gooßen, L. J. Eur. J. Org. Chem. 2012, 1431-1438. doi:10.1002/ejoc.201101770

52. Lee, H. J.; Park, K.; Bae, G.; Choe, J.; Song, K. H.; Lee, S. Tetrahedron Lett. 2011, 52, 5064-5067. doi:10.1016/j.tetlet.2011.07.091

53. Hu, J.; Zhao, N.; Yang, B.; Wang, G.; Guo, L.-N.; Liang, Y.-M.; Yang, S.-D. Chem.-Eur. J. 2011, 17, 5516-5521. doi:10.1002/chem.201003561

54. Qu, X.; Li, T.; Sun, P.; Zhu, Y.; Yang, H.; Mao, J. Org. Biomol. Chem. 2011, 9, 6938-6942. doi:10.1039/c1ob05969f

55. Park, J.; Park, E.; Kim, A.; Park, S.-A.; Lee, Y.; Chi, K.-W.; Jung, Y. H.; Kim, I. S. J. Org. Chem. 2011, 76, 2214-2219. doi:10.1021/jo200096x 
56. Park, K.; Bae, G.; Park, A.; Kim, Y.; Choe, J.; Song, K. H.; Lee, S. Tetrahedron Lett. 2011, 52, 576-580. doi:10.1016/j.tetlet.2010.11.110

57. Ranjit, S.; Duan, Z.; Zhang, P.; Liu, X. Org. Lett. 2010, 12, 4134-4136. doi:10.1021/ol101729k

58. Feng, C.; Loh, T. P. Chem. Commun. 2010, 46, 4779-4781. doi:10.1039/c0cc00403k

59. Yu, M.; Pan, D.; Jia, W.; Chen, W.; Jiao, N. Tetrahedron Lett. 2010, 51, 1287-1290. doi:10.1016/j.tetlet.2009.12.138

60. Jia, W.; Jiao, N. Org. Lett. 2010, 12, 2000-2003. doi:10.1021/ol1004615

61. Zhao, D.; Gao, C.; Su, X.; He, Y.; You, J.; Xue, Y. Chem. Commun. 2010, 46, 9049-9051. doi:10.1039/c0cc03772a

62. Park, K.; Bae, G.; Moon, J.; Choe, J.; Song, K. H.; Lee, S. J. Org. Chem. 2010, 75, 6244-6251. doi:10.1021/jo101398a

63. Zhang, W.-W.; Zhang, X.-G.; Li, J.-H. J. Org. Chem. 2010, 75, 5259-5264. doi:10.1021/jo1010284

64. Moon, J.; Jang, M.; Lee, S. J. Org. Chem. 2009, 74, 1403-1406. doi:10.1021/jo802290r

65. Kim, H.; Lee, P. H. Adv. Synth. Catal. 2009, 351, 2827-2832. doi:10.1002/adsc.200900502

66. Moon, J.; Jeong, M.; Nam, H.; Ju, J.; Moon, J. H.; Jung, H. M.; Lee, S. Org. Lett. 2008, 10, 945-948. doi:10.1021/ol703130y

67. Kolarovič, A.; Fáberová, Z. J. Org. Chem. 2009, 74, 7199-7202. doi:10.1021/jo901377b

68. Trost, B. M.; Weiss, A. H. Org. Lett. 2006, 8, 4461-4464. doi:10.1021/ol0615836

69. Poulsen, T. B.; Bernardi, L.; Alemán, J.; Overgaard, J.; Jørgensen, K. A. J. Am. Chem. Soc. 2007, 129, 441-449. doi:10.1021/ja067289q

70. Park, K.; Palani, T.; Pyo, A.; Lee, S. Tetrahedron Lett. 2012, 53, 733-737. doi:10.1016/j.tetlet.2011.11.117

71. Chandregowda, V.; Rao, G. V.; Reddy, G. C. Org. Process Res. Dev. 2007, 11, 813-816. doi:10.1021/op700054p

72. Wang, L.; Chiang, H.-C.; Wu, W.; Liang, B.; Xie, Z.; Yao, X.; Ma, W.; Du, S.; Zhong, Y. Proc. Natl. Acad. Sci. U. S. A. 2012, 109, 16743-16748. doi:10.1073/pnas.1208011109

73. Urazoe, D.; Mori, H. Process for preparing 3-aminophenylacetylenes. U.S. Patent US2006224016, Oct 5, 2006.

74. Cabri, W.; Oldani, E. Process for the industrial preparation of aminoacetylenes. U.S. Patent US5902902, May 11, 1999.

75. Bleicher, L.; Cosford, N. D. P. Synlett 1995, 1115-1116. doi:10.1055/s-1995-5220

76. Castellin, A.; De Lucchi, O.; Caporale, A. New method for the preparation of erlotinib. Eur. Pat. Appl. EP 2433931 A1, March 28, 2012.

77. Fujimura, O.; Fukunaga, K.; Honma, T.; Machida, T.; Takahashi, T. Eur. Pat. Appl. EP 1847545 A1, Oct 24, 2007.

78. Godinez, C. E.; Zepeda, G.; Mortko, C. J.; Dang, H.; Garcia-Garibay, M. A. J. Org. Chem. 2004, 69, 1652-1662. doi:10.1021/jo035517i

79. Ma, Y.; Song, C.; Jiang, W.; Wu, Q.; Wang, Y.; Liu, X.; Andrus, M. B. Org. Lett. 2003, 5, 3317-3319. doi:10.1021/ol035147k

80. Mayr, H.; Halberstadt-Kausch, I. K. Chem. Ber. 1982, 115, 3479-3515. doi:10.1002/cber.19821151104

81. Tedeschi, R. J.; Casey, A. W.; Clark, G. S., Jr.; Huckel, R. W.; Kindley, L. M.; Russell, J. P. J. Org. Chem. 1963, 28, 1740-1743. doi:10.1021/j001042a002

82. During our study we found that $\mathrm{Pd}_{2}(\mathrm{dba})_{3}$ afforded the best yield with $m$-bromoaniline, while $\mathrm{Pd}(\mathrm{OAc})_{2}$ provided better results for the other substrates.

\section{License and Terms}

This is an Open Access article under the terms of the Creative Commons Attribution License

(http://creativecommons.org/licenses/by/2.0), which permits unrestricted use, distribution, and reproduction in any medium, provided the original work is properly cited.

The license is subject to the Beilstein Journal of Organic Chemistry terms and conditions:

(http://www.beilstein-journals.org/bjoc)

The definitive version of this article is the electronic one which can be found at:

doi:10.3762/bjoc. 10.36 